\title{
Gagasan Amandemen (Ulang) UUD 1945 (Usulan untuk Penguatan DPD dan Kekuasaan Kehakiman)
}

\section{Ni'matul Huda \\ Fakultas Hukum UII Jl. Taman Siswa No. 158 Yogyakarta e-mail: nimatul@fh.uii.ac.id}

\begin{abstract}
The urgency of the re-amendment of the Constitution of 1945 is to enhance the result of the previous amendment, which is to afford better government governance in Indonesia. Needless to say that the constitution of 1945 is sacred, as also amendment can not be taken carelessly
\end{abstract}

Keywords: Amendment Of The Constitution Of 1945, The Regional Representatives Council (DPD), The Authority Of Justice.

\section{Pendahuluan}

Di awal tahun 2008, Pemerintah dan DPR sepakat menyiapkan proses perubahan kelima UUD 1945 secara menyeluruh dengan segera membentuk panitia/komisi nasional. Kesepakatan itu diambil dalam rapat konsultasi di Istana Negara Jakarta, Jumat 25 Januari 2008. Konstitusi baru hasil perubahan tersebut nantinya diharapkan dapat digunakan pemerintahan baru hasil Pemilu 2009.

Usulan Presiden Susilo Bambang Yudhoyono dan DPR untuk membentuk panitia/komisi nasional yang mempersiapkan Perubahan V UUD 1945 memunculkan sikap yang beragam di masyarakat. Sebagian anggota MPR dan Forum Konstitusi kurang sependapat dengan usulan pembentukan panitia/komisi nasional tersebut. Mereka memandang kewenangan membentuk panitia/komisi tersebut ada pada MPR dan bukan domain Presiden. ${ }^{1}$ Di sisi lain, sebagian anggota DPD dan kalangan ahli hukum tata negara mendukung gagasan Presiden dan DPR tersebut. ${ }^{2}$

\footnotetext{
${ }^{1}$ Lihat, Kompas, 31 Januari 2008.

${ }^{2}$ Lihat Kompas, 1 Pebruari 2008.
} 
Secara normatif memang kewenangan untuk melakukan perubahan UUD 1945 ada di tangan MPR, sehingga dipandang lebih tepat jika yang membentuk paniti/komisi nasional tersebut adalah MPR. Akan tetapi, usulan perubahan konstitusi tidak harus muncul dari MPR. Setiap warga negara yang memiliki kesadaran dan kepedulian terhadap masa depan bangsa ini berhak untuk mengusulkan perubahan konstitusi, dan selanjutnya dikaji kembali oleh MPR semua usulan yang masuk kepadanya. Semua anggota MPR RI periode 2004-2009 sudah selayaknya segera mengkaji ulang berbagai usulan perubahan yang sudah diwacanakan di masyarakat baik yang diusulkan Komisi Konstitusi, Forum Rektor, DPD, maupun berbagai pihak yang menaruh perhatian terhadap hasil amandemen UUD 1945.

Usulan Presiden dan DPR untuk membentuk panitia/komisi nasional patut didukung karena hasil amandemen yang telah dilakukan MPR periode 1999-2004 masih menyisakan sejumlah persoalan. Untuk itu, berbagai ide penyempurnaan hasil amandemen UUD 1945 patut untuk diapresiasi secara konstruktif. Dalam tulisan ini penulis hanya ingin membatasi diri pada kajian pentingnya penguatan kelembagaan DPD dan penyempurnaan desain kelembagaan kekuasaan kehakiman.

\section{Hasil Amandemen UUD 1945 yang Belum Sempurna}

Hasil perubahan yang dilakukan oleh MPR tahun 1999-2002 merupakan kontribusi positif terhadap upaya perbaikan sistem ketatanegaraan Indonesia ke depan. Dengan perubahan pasal-pasal tersebut, hasil perubahan MPR telah berhasil meletakkan sendi-sendi checks and balances, termasuk membatasi kekuasaan eksekutif, MPR telah berhasil mengubah dengan tegas tentang darimana kedaulatan diperoleh (locus of souvereignty). MPR yang terdiri anggota-anggota DPR dan anggotaanggota DPD merupakan realisasi demokrasi perwakilan. Sebagai lembaga negara, MPR hanya eksis ketika DPR dan DPD berada dalam sidang gabungan (joint session). Inovasi politik dan hukum melalui perubahan UUD 1945 oleh MPR era reformasi juga berkaitan dengan pemilihan langsung anggota, Presiden dan Wakil Presiden. Perjuangan politik dan hukum yang dilakukan MPR merupakan awal dari desakralisasi terhadap keberadaan UUD 1945. Keberhasilan MPR dalam Perubahan UUD 1945 merupakan pemutusan mata rantai kemandegan konstitusional menuju sistem ketatanegaraan yang lebih baik dan bersih. Komitmen MPR 
terhadap perubahan begitu besar tanpa mengabaikan nilai-nilai khusus bangsa Indonesia. Tercapainya kesepakatan nasional tentang Pembukaan UUD 1945, bentuk Negara Kesatuan dan Republik, serta sistem Pemerintahan Presidensiil merupakan bukti komitmen historis Perjanjian Luhur suatu bangsa.

Perubahan UUD 1945 yang pertama sampai dengan keempat jelas bersifat mendasar dan mencakup materi yang sangat banyak, sehingga telah mengubah sistematika, baik perumusan formalnya maupun sistematika berpikir UUD 1945. Dengan demikian, Perubahan UUD 1945 sudah tidak dapat lagi disebut menggunakan tradisi Amerika Serikat yang dijadikan rujukan dalam rangka pelaksanaan perubahan UUD 1945. Oleh karena itu, sebaiknya, teknik dan prosedur yang diacu oleh ketentuan Pasal 37 UUD 1945 itu haruslah dipahami dalam pengertian model tradisi Eropa, bukan Amerika Serikat. ${ }^{3}$

Sejumlah kalangan masyarakat menilai hasil Perubahan UUD 1945 oleh MPR jauh dari memuaskan. Perubahan konstitusi yang seharusnya dilakukan oleh lembaga independen semacam Komisi Konstitusi, - belajar dari pengalaman negara-negara lain yang sukses melakukan reformasi konstitusi (Thailand, Filipina, Afrika Selatan dll.) - tetapi dalam konteks Indonesia, perubahan justru dilakukan oleh lembaga yang seharusnya menjadi obyek dari perubahan. Karena itu menurut Bambang Widjojanto, sejak awal sudah dapat diduga, arah dan substansi perubahan tidak akan mendasar guna mengabdi secara utuh pada kedaulatan rakyat serta membangun sistem kekuasaan yang demokratis dengan cara membenahi carut-marutnya sistem kekuasaan. ${ }^{4}$

Pentingnya melembagakan proses reformasi konstitusi di luar institusi politik konvensional didasarkan beberapa alasan. Reformasi konstitusi yang terjadi sejalan dengan pergolakan politik akibat transisi dari pemerintahan otoriter, sarat benturan kepentingan politik antara kelompok status quo, yang masih membawa dan mempertahankan semangat otoriter, dengan kelompok reformis yang berusaha menuju ke negara demokratis. ${ }^{5}$

${ }^{3}$ Bagir Manan, Teori dan Politik Konstitusi, FH UII Press, Yogyakarta, 2003, hlm. 232.

${ }^{4}$ Bambang Widjojanto, “Komisi Konstitusi, Instrumen untuk Mengatasi Krisis Konstitusional”, dalam Bambang Widjojanto dkk. (Editor), Konstitusi Baru Melalui Komisi Konstitusi Independen, Pustaka sinar harapan, 2002, hlm. 198.

${ }^{5}$ Guillermo O'Donnel, Philippe C. Schmitter dan Laurence Whitehead (Editor), Transition from Authoritarian Rule: Prospect for Democracy, 1986. 
Dalam peta politik demikian menurut Denny Indrayana, reformasi konstitusi yang tidak dilepaskan dari konflik politik, dengan menyerahkannya semata-mata kepada lembaga perwakilan rakyat seperti MPR, akan cenderung terkontaminasi dengan virus kompromi politik jangka pendek yang biasanya menjadi solusi pragmatis dari konflik politik transisi. Oleh karena itu, akan lebih baik bila proses reformasi konstitusi diserahkan pada lembaga profesional yang independen dan non partisan sebagaimana Komisi Konstitusi. ${ }^{6}$

Hal senada juga dikemukakan oleh Jimly Asshiddiqie ${ }^{7}$ yang mengatakan, para anggota Majelis Permusyawaratan Rakyat tidak memiliki kesempatan waktu yang memadai untuk terlebih dahulu memperdebatkan secara mendalam. Kalaupun pilihan-pilihan konseptual yang didasarkan atas pertimbangan akademis yang matang sudah dipikirkan oleh anggota Majelis, suasana dan dinamika yang mempengaruhi proses pembahasan rancangan perubahan itu juga sangat dipengaruhi oleh kepentingankepentingan yang terlibat di dalamnya. Keadaan ini menyebabkan pilihanpilihan yang menyangkut kebenaran akademis seringkali terpaksa dikesampingkan oleh pilihan-pilihan yang berkenaan dengan kebenaran politik. Untuk itu, yang sebaiknya merancang penyusunan kembali naskah akademik Undang-Undang Dasar adalah sebuah Panitia UUD yang dibentuk tersendiri, yang dapat dinamakan Komisi Konstitusi atau Panitia Penyusunan Undang-Undang Dasar.

Kritik tajam juga dilontarkan oleh Mukthie Fadjar, ${ }^{8}$ yang mengatakan dalam melakukan perubahan-perubahan terhadap UUD 1945 tersebut ternyata sejak semula MPR memang tidak memiliki visi dan misi yang jelas yang disepakati dan dirumuskan secara tegas, atau dengan kata lain tidak memiliki paradigma perubahan yang diinginkan dengan perubahan konstitusi, sehingga menuai banyak kritik baik dalam proses maupun dalam substansi, dan bahkan secara ekstrim ada dua kubu pendapat yang berhadapan secara diametral, yaitu yang menilai MPR telah 'kebablasan' dalam melakukan perubahan terhadap UUD 1945 sehingga harus dihentikan, dan yang lain menganggap MPR tidak mampu atau 'kacau balau' dalam melakukan perubahan sehingga diharapkan "melempar

${ }^{6}$ Bambang Widjojanto dkk. (Editor), Konstitusi..., Op.Cit., hlm. 178.

${ }^{7}$ Jimly Asshiddiqie, "Telaah Akademis Atas Perubahan UUD 1945”, Jurnal Demokrasi E HAM, Vol.1, No. 4, September-November 2001, hlm. 10.

${ }^{8}$ A. Mukthie Fadjar, Reformasi Konstitusi Dalam Masa Transisi Paradigmatik, InTRANS, Malang, 2003, hlm. 59-60. 
handuk" menyerahkan tugas perubahan atau bahkan penyusunan konstitusi baru kepada sebuah Komisi Konstitusi yang independen, sedangkan MPR hanya menetapkannya saja.

Sebagaimana diketahui, UUD 1945 telah menentukan prosedur perubahannya dalam Pasal 37. Artinya UUD 1945 tidak melarang kalau akan diubah tetapi tidak mengatur teknik perubahan yang harus dilakukan apakah dengan memakai cara Amerika Serikat atau Eropa Kontinental. Dan juga tidak menentukan secara tegas institusi negara yang berwenang melakukan perubahan terhadap UUD, tetapi dari Perubahan Pertama sampai dengan Perubahan Keempat, MPR beranggapan bahwa dirinyalah yang paling berwenang melakukan perubahan. Kritik atas kewenangan MPR ini, terutama dari kalangan yang menghendaki perubahan dilakukan oleh sebuah Komisi Konstitusi yang independent, tetapi dijawab oleh MPR dengan mengubah Pasal 3 UUD 1945 dengan menambahkan kewenangan MPR untuk mengubah UUD, di samping kewenangan untuk menetapkan UUD (Perubahan Ketiga). ${ }^{9}$

Dari hasil kajian komprehensif yang dilakukan sejak bulan Oktober 2003 sampai dengan bulan April 2004 terhadap hasil perubahan UUD 1945 oleh MPR, Komisi Konstitusi berpendapat antara lain:10

1. Hasil Perubahan UUD 1945 yang dilakukan oleh MPR tahun 19992002 merupakan kontribusi positif terhadap upaya perbaikan sistem ketatanegaraan Indonesia ke depan. Dengan perubahan pasal-pasal tersebut, hasil perubahan MPR telah berhasil meletakkan sendi-sendi checks and balances, termasuk membatasi kekuasaan eksekutif, MPR telah berhasil mengubah dengan tegas tentang dari mana kedaulatan diperoleh (locus of souvereignty). MPR yang terdiri anggota-anggota DPR dan anggota-anggota DPD merupakan realisasi demokrasi perwakilan. Sebagai lembaga negara, MPR hanya eksis ketika DPR dan DPD berada dalam sidang gabungan (joint session). Inovasi politik dan hukum melalui perubahan UUD 1945 MPR era reformasi juga berkaitan dengan pemilihan langsung anggota, Presiden dan Wakil Presiden.

2. Perjuangan politik dan hukum yang dilakukan MPR merupakan awal dari desakralisasi terhadap keberadaan UUD 1945. Keberhasilan MPR

\footnotetext{
${ }^{9}$ A. Mukhie Fadjar, Hukum Konstitusi dan Mahkamah Konstitusi, Konstitusi Press, Jakarta dan Citra Media, Yogyakarta, 2006, hlm. 23.

${ }^{10}$ Komisi Konstitusi, Buku I Naskah Akademik Kajian KomprehensifKomisi Konstitusi tentang Perubahan UUD Negara Republik Indonesia Tahun 1945, MPR RI, Jakarta, 2004, hlm. 122-127.
} 
dalam Perubahan UUD 1945 merupakan pemutusan mata rantai kemandegan konstitusional menuju sistem ketatanegaraan yang lebih baik dan bersih. Komitmen MPR terhadap perubahan begitu besar tanpa mengabaikan nilai-nilai khusus bangsa Indonesia. Tercapainya kesepakatan nasional tentang Pembukaan UUD 1945, bentuk Negara Kesatuan dan Republik, serta sistem Pemerintahan Presidensiil merupakan bukti komitmen historis Perjanjian Luhur suatu bangsa.

3. Tidak dapat dipungkiri bahwa hasil perubahan UUD 1945 yang telah dilakukan MPR dalam beberapa hal mengandung kontradiksi, baik secara teoritis konseptual maupun praktek ketatanegaraan. Meskipun perubahan terhadap materi muatan meliputi lebih dari 50\%, dan terdiri dari 207 ayat, namun UUD 1945 masih tetap ada. Di samping itu juga terdapat inkonsistensi substansi baik yuridik maupun teoritik. Strukturisasi atau sistematisasi pasal-pasal tambahan yang tidak konsisten tersebut melahirkan inovasi politik dan hukum dari Komisi Konstitusi. Konstitusionalisasi yang dilakukan Komisi Konstitusi dibuktikan dengan lahirnya pasal-pasal tambahan. Sebagai contoh ialah pemilihan calon Presiden independen (Pasal 6A), pemberdayaan kewenangan DPD yang sejajar dengan DPR (Pasal 22C). Selain itu dalam penegakkan hukum juga terjadi inovasi. Hal ini terbukti yang selain dari Polri, juga diatur Kejaksaan dan Ombudsman (Pasal 24 D,E,F), pemilihan Kepala Daerah/Wakil Kepala Daerah secara langsung (Pasal 18 ayat (4)), asas retroaktif dalam kasus HAM berat (Pasal 28I), penyandang cacat (Pasal 34) dan kemerdekaan Pers yang dijamin dan diatur dalam undang-undang, keterlibatan rakyat dalam perubahan UUD 1945 dan Komisi Konstitusi (Pasal 37 ayat (7)).

4. Tiadanya kerangka acuan atau naskah akademik dalam melakukan perubahan UUD 1945 merupakan salah satu sebab timbulnya inkonsistensi teoritis dan konsep dalam mengatur materi muatan UUD. Hal ini juga berlaku terhadap prosedur perubahan UUD yang tidak melibatkan rakyat. Metode participatory yang dipergunakan oleh kebanyakan negara-negara modern, perlu digunakan dalam melakukan perubahan terhadap UUD.

Belakangan diketahui bahwa hasil Komisi Konstitusi yang dilaporkan kepada Badan Pekerja MPR ternyata kurang mendapat respon positif, bahkan kabarnya hasil kajian Komisi Konstitusi "ditolak" oleh MPR. Karena Komisi Konstitusi dinilai telah melampaui tugasnya yang mestinya 
hanya melakukan pengkajian secara komprehensif Perubahan UUD 1945 hasil karya MPR, tetapi malah mengusulkan perubahan terhadap hasil Perubahan UUD 1945.

Rupanya antara BP MPR dengan Komisi Konstitusi terjadi perbedaan tafsir mengenai arti "pengkajian komprehensif Perubahan UUD 1945". Komisi Konstitusi memberi makna yang luas, yaitu tidak hanya mencakup hal-hal seputar hasil Perubahan UUD 1945 yang telah dilakukan oleh MPR sebanyak empat tahap, tetapi juga mencakup pemikiran filosofis pada founding fathers ketika membuat rumusan naskah UUD dalam sidang BPUPKI dan PPKI, sehingga hasil Komisi Konstitusi terdiri atas Naskah Akademik hasil pengkajian Perubahan UUD 1945 (Buku I) dan Usulan Perubahan Pasal-pasal UUD 1945 (Buku II). ${ }^{11}$

Sementara itu, menurut BP MPR pengkajian secara komprehensif berarti melakukan kajian terhadap Perubahan UUD 1945, bukan melakukan kegiatan untuk membuat usulan perubahan terhadap Perubahan UUD 1945. Hasil Komisi Konstitusi diharapkan lebih mengarah kepada bagaimana mengimplementasikan Perubahan UUD 1945, antara lain dalam bentuk gagasan-gagasan ilmiah mengenai agenda pembentukan UU organik sebagai perangkat hokum pelaksanaan UUD 1945 agar dapat operasional dan memberi manfaat dalam peningkatan kualitas penyelenggaraan negara.

Perbincangan di seputar hasil perubahan UUD 1945 akhir-akhir ini marak kembali dan mencakup kalangan yang lebih meluas, tidak hanya oleh akademisi dan politisi, tetapi hampir semua kalangan masyarakat bebas memperbincangkan UUD 1945. Sebuah suasana demokrasi yang benar-benar hidup dan belum pernah kita rasakan pada periode sebelumnya. Sebelum reformasi perdebatan tentang UUD 1945 'ditabukan' secara politik, masyarakat tidak punya tempat atau ruang untuk mengekspresikan dan menghidupkan demokrasi karena di setiap sudut ruang kebebasan selalu saja ada 'kecurigaan' yang akan merongrong kekuasaan dan mengganggu ke-'sakralan' UUD 1945.

Setelah UUD 1945 hasil perubahan berjalan kurang lebih 5 tahun, eksistensi UUD 1945 kembali dipersoalkan. Konstitusi seakan menjadi "terdakwa" di tengah karut-marutnya kondisi bangsa. Berbagai ketimpangan dan kelemahan desain yang selama ini dikhawatirkan oleh sejumlah kalangan, mulai bermunculan satu demi satu. Benturan

${ }^{11}$ A. Mukhie Fadjar, Hukum Konstitusi..., Op.Cit., hlm. 63-64. 
kewenangan antar lembaga negara tidak terelakkan, sebagai contoh, misalnya konflik antara Mahkamah Agung (MA) dengan Komisi Yudisial (KY), Dewan Perwakilan Rakyat (DPR) dengan Dewan Perwakilan Daerah (DPD). Persoalan lain, kemunculan berbagai lembaga negara independen atau komisi-komisi negara independen yang akhir-akhir ini marak, juga seringkali menimbulkan benturan kewenangan (overlapping) diantara lembaga independen atau juga dengan lembaga lainnya, misalnya Komisi Pemberantasan Korupsi (KPK) dengan Kepolisian dan Kejaksaan, KPK dengan MA, KPK dengan Menteri Sekretaris Negara, dan lain-lain, karena belum didesain secara jelas dalam ketatanegaraan kita.

Melihat fenomena karut-marutnya implementasi ketatanegaraan di bawah UUD 1945 (Perubahan), setidaknya ada tiga kelompok masyarakat yang berebut pengaruh mengenai eksistensi konstitusi. Kelompok pertama, boleh disebut Komite Nasional Penyelamat Pancasila dan UUD 1945. Di dalam Presidium Komisi Nasional itu terdapat nama KH Abdurrahman, Soetardjo Soerjogoeritno, Amin Aryoso, Ridwan Saidi, dan Tyasno Sudarto yang memimpin Gerakan Revolusi Nurani. ${ }^{12}$ Mereka menilai, diubahnya UUD 1945 menjadi UUD 2002 adalah bentuk intervensi asing yang menyebabkan kehidupan kenegaraan mengarahkan pada individualisme, materialisme, liberalisme sehingga menjauh dari masyarakat yang adil dan makmur. Mereka menuntut supaya kembali saja ke naskah UUD 1945 asli $^{13}$ (sebelum perubahan) bahkan kalau perlu dengan Dekrit. ${ }^{14}$

\footnotetext{
${ }^{12}$ Budiman Tanuredjo, "Konstitusi di Tengah Tarikan Kepentingan”, Kompas, 7 Maret 2007

${ }^{13}$ Menurut Buyung Nasution sikap yang menuntut kembali ke UUD 1945 yang "asli" atau yang " murni dan konsekuen", ibarat memutar jarum jam sejarah ke belakang, ke zaman Demokrasi Terpimpin (Prde Lama) atau Demokrasi Pancasila (Orde Baru) yang anti demokrasi. Banyak hasil penelitian ilmiah menunjukkan, UUD 1945 memiliki kelemahan atau cacat konseptual bagi pegangan berbangsa dan bernegara. Lihat dalam Adnan Buyung Nasution, "Kembali Ke UUD 45 Antidemokrasi", Kompas, 10 Juli 2006. Pendapat senada dikemukakan Koalisi Konstitusi Baru. Keinginan kelompok warga yang secara sistematis berkampanye untuk kembali ke UUD 1945 sebelum perubahan harus dilawan. Keinginan kembali ke UUD 1945 sebelum perubahan hanya akan membawa ke zaman dengan sistem pemerintahan otoritarian-birokratik lagi. Bahkan ide itu bisa jadi cuma pintu masuk mencapai agenda tersembunyi lain. Lihat “Upaya Kembali ke Konstitusi Lama Harus “Dilawan", Kompas, 6 Pebruari 2007.

${ }^{14}$ Presiden Susilo Bambang Yudhoyono dalam pidato sambutan di depan peserta Kursus Singkat Angkatan Ke-14 Lembaga Ketahanan Nasional di Istana Negara tanggal 6 Juli 2006, menyatakan menghormati pemikiran sejumlah pihak yang menginginkan kembali ke UUD 1945 sebelum empat kali diubah. Namun, kalau ada
} 
Kelompok kedua, mendorong dilakukannya Perubahan Kelima UUD 1945. Dimotori oleh 128 anggota DPD dan didukung anggota Fraksi Kebangkitan Bangsa MPR, anggota Fraksi PKS, dan Fraksi PBR. Kelompok ini mengusulkan perubahan Pasal perubahan Pasal 22D ayat (1), (2) dan (3). Alasan yang diajukan, untuk mengefektifkan posisi DPD dalam memperjuangkan kepentingan daerah, serta dalam rangka meningkatkan peran DPD dalam sistem ketatanegaraan RI, khususnya dalam mengembangkan sistem checks and balances antar lembaga negara.

Kelompok ketiga, didominasi kekuatan politik mayoritas di DPR, Partai Golkar, PDIP, PPP dan PAN. Mereka menolak ide perubahan UUD 1945. Menurut Wakil Ketua Umum PPP, perubahan konstitusi hanya untuk meningkatkan peran DPD dirasa terlalu cepat dan waktunya tidak tepat. Demikian pula pendapat Sekjen PDIP, perubahan konstitusi hanya menjadi keinginan sekelompok elite politik.

Di luar ketiga kelompok tersebut, ada pula yang mengusulkan restorasi perubahan UUD 1945. Dalam konsep ini, konstitusi dikembalikan pada naskah asli, sementara hasil perubahannya ditempatkan pada bagian tambahan (addendum). Gagasan ini dimunculkan oleh ahli hukum Dimyati Hartono dalam bukunya Restorasi Amandemen UUD 1945. Tahapan yang diusulkan Dimyati, kembali dulu ke naskah asli UUD 1945, kemudian menganalisis hasil perubahan konstitusi mengenai apa yang salah dan mana yang bisa diteruskan, kemudian menyusun hasilnya dalam tata naskah restorasi perubahan UUD 1945 yang lengkap. Dalam naskah itu dimuat naskah Proklamasi 17 Agustus 1945, Pembukaan UUD 1945, Batang Tubuh, Penjelasan, dan hasil analisis terhadap hasil perubahan yang diformat dalam tambahan. ${ }^{15}$

\section{Usulan Penguatan DPD}

Akhir-akhir ini MPR aktif melakukan sosialisasi hasil perubahan UUD 1945 dan sekaligus 'berkampanye' menggalang dukungan agar dilakukan perubahan kembali UUD 1945, khususnya mengenai keberadaan MPR supaya lebih ditingkatkan lagi menjadi kelembagaan yang permanen. Karena, MPR dalam desain yang sekarang (hasil perubahan UUD 1945)

pikiran kembali ke UUD 1945, solusinya bukan dengan Dekrit Presiden. Bertanyalah kepada seluruh rakyat Indonesia dan bagaimana MPR. Lihat "Dekrit Bukan Solusi", Kompas, 7 Juli 2006.

${ }^{15}$ Kompas, 6 Maret 2007. 
tidak jelas kedudukannya, berkayuh antara sistem dua kamar ataukah tiga kamar. Demikian pula dengan DPD, belakangan ini juga gencar mencari dukungan untuk penguatan DPD melalui perubahan Pasal 22D UUD 1945. Mengapa butuh penguatan? Karena desain sistem parlemen pasca perubahan UUD 1945 tidak tegas mengikuti sistem bikameral ataukah trikameral? Kekaburan sistem tersebut berpengaruh terhadap kinerja DPD dan hubungan kelembagaan antara DPD dengan DPR, DPD dengan Presiden. DPD dalam konstruksi UUD 1945 lebih memperlihatkan sebagai penunjang atau auxiliary terhadap fungsi DPR di bidang legislasi, sehingga DPD paling jauh hanya dapat disebut sebagai co-legislator, daripada legislator yang sepenuhnya. Kewenangan legislasi dari DPD sangat terbatas.

Parlemen bikameral memang biasanya dihubungkan dengan bentuk negara federasi yang memerlukan dua kamar majelis. Kedua majelis itu perlu diadakan untuk maksud melindungi formula federasi itu sendiri. Tetapi, dalam perkembangannya - bersamaan dengan pergeseran kecenderungan ke arah bentuk negara kesatuan - maka sistem bikameral itu juga dipraktekkan di lingkungan negara-negara kesatuan. Dua alasan utama yang dapat dikemukakan penggunaan sistem bikameral ini adalah: ${ }^{16}$ a. Adanya kebutuhan akan perlunya suatu keseimbangan yang lebih stabil antara pihak eksekutif dan legislatif, the unbridled power of a single chamber being restrained by the creation of a Second Chamber recruited on a different basis; $b$. Keinginan untuk membuat sistem parlementer berjalan, jika tidak lebih efisien, setidak-tidaknya lebih lancar (lebih smooth), melalui suatu majelis (chamber) yang disebut revising chamber untuk memelihara a careful check on the sometimes hasty decisions of a first Chamber.

Alasan yang kedua itulah yang biasa disebut oleh para ahli dengan sistem 'double check' yang memungkinkan setiap produk legislatif diperiksa dua kali, sehingga terjamin kualitasnya sesuai dengan aspirasi rakyat. Akan tetapi, syaratnya jelas bahwa keanggotaan kedua kamar parlemen itu benar-benar yang mewakili aspirasi yang berbeda satu sama lain, sehingga keduanya benar-benar mencerminkan gabungan kepentingan seluruh rakyat. DPD mewakili rakyat dalam konteks kedaerahan dan dengan orientasi kepentingan daerah. Sedangkan DPR mewakili rakyat

${ }^{16}$ Jimly Asshiddiqie, Pergumulan Peran Pemerintah dan Parlemen Dalam Sejarah Telaah Perbandingan Konstitusi Berbagai Negara, UI Press, Jakarta, 1996, hlm. 39. 
pada umumnya dengan orientasi kepentingan nasional. Untuk menjamin hal ini, maka prosedur pemilihan untuk anggota DPR berbeda dari prosedur untuk pemilihan anggota DPD.

Akan tetapi, ide bikameralisme atau struktur parlemen dua kamar itu mendapat tentangan yang keras dari kelompok-kelompok konservatif di Panitia Ad Hoc Perubahan UUD 1945 di MPR 1999-2002, sehingga yang disepakati adalah rumusan yang sekarang yang tidak dapat disebut menganut sistem bikameral sama sekali. ${ }^{17}$

Penerapan sistem bikameral itu, dalam prakteknya sangat dipengaruhi oleh tradisi, kebiasaan, dan sejarah ketatanegaraan negara yang bersangkutan. Seperti halnya negara federasi, negara kesatuan juga bertujuan melindungi wilayah tertentu, melindungi etnik, dan kepentingan-kepentingan khusus dari golongan rakyat tertentu (seperti kelompok kepentingan, golongan minoritas, dan sebagainya) dari suara mayoritas (tirani mayoritas).

Jadi, sebenarnya tidak banyak perbedaan apakah sistem unikameral ${ }^{18}$ atau bikameral yang digunakan dalam negara kesatuan atau federasi itu. Yang penting bahwa sistem majelis tunggal atau ganda itu dapat benarbenar berfungsi untuk menyalurkan aspirasi rakyat dalam mengawasi jalannya pemerintahan.

Ada negara yang menjalankan sistem dua kamar karena latar belakang kesejarahan. Inggeris menjalankan sistem dua kamar, antara lain untuk tetap memelihara kehadiran perwakilan kaum bangsawan di samping rakyat umum. Sistem dua kamar di Inggeris tidak terlepas dari proses demokratisasi badan perwakilan. Semula badan perwakilan di Inggris hanya terdiri dari kaum bangsawan atau yang mewakili kelompok agama dan institusi tertentu. Demokratisasi dan tumbuhnya kelas sosial baru (kelas menengah), kemudian menuntut perwakilan yang mewakili rakyat umum. Lahirlah Majelis Rendah (House of Commons) disamping Majelis Tinggi (House of Lords).

${ }^{17}$ Jimly Asshiddiqie, "Kata Pengantar" dalam Mustofa Muchdhor (Penyunting), Bikameral Bukan Federal, Kelompok DPD di MPR RI, Jakarta, 2006, hlm. xv.

${ }^{18}$ Fungsi dewan atau majelis legislatif dalam sistem unikameral itu terpusat pada satu badan legislatif tertinggi dalam struktur negara. Isi aturan mengenai fungsi dan tugas parlemen unikameral beragam dan bervariasi dari satu negara ke negara lain, tetapi pada pokoknya serupa bahwa secara kelembagaan fungsi legislatif tertinggi diletakkan sebagai tanggungjawab satu badan tertinggi yang dipilih oleh rakyat. Lihat Jimly Asshiddiqie, Pergumulan ..., Op.Cit., hlm. 33-36. 
Sistem dua kamar di Amerika Serikat, merupakan hasil kompromi antara negara bagian yang berpenduduk banyak dengan yang berpenduduk sedikit. House of Representatives (DPR) mewakili seluruh rakyat. Setiap negara bagian diwakili sesuai dengan jumlah penduduk. Senate (Senat) mewakili negara bagian. Setiap negara bagian diwakili dua orang Senator tanpa membeda-bedakan negara bagian yang berpenduduk banyak (seperti New York atau California) dengan yang berpenduduk lebih kecil (seperti Alaska, atau Nevada). ${ }^{19}$

Perubahan susunan MPR yang terdiri dari DPR dan DPD, seolah mengarah pada pembentukan sistem dua kamar (bikameral), Tetapi dari susunan yang menyebutkan terdiri dari anggota-anggota DPR dan DPD, tidak tergambar konsep dua kamar. Dalam susunan dua kamar, bukan anggota yang menjadi unsur, tetapi badan yaitu DPR dan DPD. Seperti Congress Amerika Serikat yang terdiri dari Senate dan House of Representatives. Kalau anggota yang menjadi unsur, maka MPR adalah badan yang berdiri sendiri di luar DPR dan DPD.

Salah satu konsekuensi gagasan dua kamar (terdiri dari DPR dan DPD), perlu nama bagi badan perwakilan yang mencerminkan dua unsur perwakilan tersebut, seperti Congress sebagai nama badan perwakilan yang terdiri dari Senate dan House of Representatives. Nama yang digagaskan untuk badan perwakilan dua kamar di Indonesia adalah tetap menggunakan Majelis Permusyawaratan Rakyat (MPR). Sebagai konsekuensi penggunaan nama MPR sebagai nama sistem dua kamar, maka MPR tidak lagi menjadi suatu lingkungan jabatan (lingkungan kerja tetap tersendiri) yang memiliki lingkungan wewenang sendiri. Wewenang MPR (baru) melekat pada wewenang DPR dan DPD, atau seperti dalam UUD Amerika Serikat dan lain-lain negara dengan sistem dua kamar, yang ditentukan adalah wewenang Congress, Parliament, Staten Generaal yang pelaksanaannya dilakukan oleh kamar-kamar perwakilannya. ${ }^{20}$

Konstitusi tidak menentukan hubungan DPR dengan DPD baik sebagai hubungan antar kamar maupun hubungan "antar kelompok anggota" di bawah naungan MPR. Artinya tidak ada hubungan antar lembaga (atau antar kamar). Dengan demikian, MPR merupakan parlemen unikameral dengan keanggotaan ganda (utusan partai-partai dan utusan

\footnotetext{
${ }^{19}$ Bagir Manan, Teori dan ...,Op.Cit. , hlm. 58.

${ }^{20}$ Bagir Manan, DPR..., Op.Cit., hlm. 54.
} 
daerah-daerah). Pertanyaan berikutnya, dimana letak DPR dan DPD dalam konteks metamorfosis MPR dan perubahan proses legislasi?

Ketika berlangsung fungsi inter-kameral antara DPR-DPD, proses itu dapat disebut sebagai 'arena' joint session DPR-DPD: ketika DPR mengundang DPD untuk ikut membahas RUU yang terkait dengan otonomi daerah; ketika kepada DPR pihak DPD mengajukan RUU yang terkait dengan otonomi daerah atau meminta pertimbangan tentang RAPBN, ketika DPD meminta pertimbangan dalam pemilihan anggota BPK, dan ketika DPR-DPD menerima Haptah BPK. Di sini DPD hanya memiliki "fungsi konsultatif".

Jelas bahwa pola hubungan DPR-DPD-Presiden bukan merupakan MPR sebagai joint session, karena wewenang bersama ketiga lembaga tersebut bukan merupakan wewenang MPR dan pola hubungan ketiganya bukan di bawah naungan MPR. Pola hubungan "kamar-kamar legislatif" ini boleh saja disebut tipe hibrida, yaitu "legislatif tiga kamar" (three chamber legislature), tetapi dengan fungsi pengambilan keputusan hanya di tangan dua kamar (DPR dan Presiden). Tentu saja tidak tepat menyebut pola hubungan DPR-DPD-MPR sebagai parlemen tiga kamar (three chamber parliament). ${ }^{21}$

Untuk agenda perubahan kelima UUD 1945, perlu ada rencana induk (grand design) sebelum mengamandemen kembali UUD 1945. Disamping itu, perlu dilakukan penataan ulang lembaga legislasi yaitu DPR-DPDPresiden. Selain melakukan penguatan fungsi legislasi DPD, kekuasaan presiden dalam pembentukan undang-undang harus mulai dibatasi dan dialihkan ke DPD dan DPR, Presiden harus diberi hak tolak atau hak veto.

Ada beberapa skenario pemberdayaan DPD yang diusulkan sejumlah ahli dan politisi. Pertama, dalam bidang legislasi kedudukan DPD tidak perlu sepenuhnya setara atau sama luasnya dengan DPR. Kedua, kewenangan legislatif DPD cukup terbatas pada bidang-bidang yang sekarang sudah tercantum dalam UUD 1945 dan itu pun tetap bersama dengan DPR. Ketiga, kewenangan legislasi DPD dirumuskan dengan berbagai cara, seperti di negara-negara lain, mulai dari hak menolak (veto), mengembalikan ke DPR, atau hanya menunda. Keempat, kewenangan pengawasan DPD memiliki kekuatan hukum sama dengan DPR agar fungsi pengawasan efektif. Untuk menghindari duplikasi dengan DPR,

${ }^{21}$ Krisna Harahap, Konstitusi Republik Indonesia Sejak Proklamasi Hingga Reformasi, PT Grafitri Budi utami, Jakarta, 2004, hlm. 233. 
dapat diatur pembagian kewenangan dan tanggungjawab pengawasan antara keduanya.

Demikian pula halnya dengan MPR, meskipun MPR dilengkapi dengan sejumlah kewenangan oleh UUD 1945 (Perubahan) sebagaimana dibahas di atas, tetapi kewenangan tersebut sifatnya insidental. Kewenangan mengubah UUD, memilih Wakil Presiden dalam hal terjadi kekosongan Wakil Presiden, memilih Presiden dan Wakil Presiden jika Presiden dan Wakil Presiden mangkat, berhenti, diberhentikan, atau tidak dapat melakukan kewajibannya dalam masa jabatannya secara bersamaan, sifatnya insidentil. Dengan demikian, MPR yang merupakan forum joint session DPR dan DPD tidak perlu permanen sehingga lebih tepat pimpinan MPR ad hoc saja, tidak perlu sekretariat dan pimpinan yang terpisah. Kewenangan DPD juga perlu ditambah 'kualitasnya' agar aspirasi daerah mendapat tempat yang lebih proporsional, sehingga semangat otonomi daerah yang diamanatkan UUD 1945 dapat segera terwujud dan mendapat pengawalan dari DPD.

Usulan amandemen UUD 1945 yang diusung oleh DPD melalui amandemen 'terbatas' pada Pasal 22D, dapat dipandang sebagai usulan yang sangat elitis. Kenapa? Pertama, dari hasil amandemen UUD 1945 yang telah berlangsung empat kali dari tahun 1999 s/d 2002 menunjukkan bahwa salah satu titik lemahnya terletak pada lembaga yang melakukan amandemen yaitu MPR. Kalau amandemen masih tetap dilakukan oleh MPR sendiri dan mendesakkan waktu harus pada sisa periode ini (2007 s/ d 2009), jangan-jangan kesalahan yang sama akan berulang, apalagi usulan kali ini berkaitan dengan kelembagaan MPR. Nampaknya diperlukan semacam Komisi Konstitusi yang independen untuk melakukan persiapan dan kajian amandemen. Kedua, DPD dan MPR mendesak untuk ada penguatan di masing-masing lembaga agar lebih memperjelas kedudukan masing-masing. Kalau terhadap dua lembaga ini akan dilakukan perubahan, pasti akan berpengaruh terhadap pasal-pasal yang lain. Misalnya, hubungan antara DPD dengan DPR; DPD dengan MPR; DPD dengan Presiden; DPD dengan Daerah. Demikian pula kalau dilakukan perubahan terhadap kelembagaan MPR, juga akan bersinggungan dengan lembaga lain, misalnya hubungan antara MPR dengan Presiden dan Wakil Presiden; MPR dengan DPD; MPR dengan DPD dan DPR. Apakah MPR sudah melakukan kajian yang komprehensif terhadap kompleksitas persoalan tersebut.

Usulan perubahan UUD 1945 yang diajukan oleh DPD nampaknya perlu disinkronkan dengan kelembagaan yang lain supaya 
penyempurnaan UUD 1945 pasca amandemen 2002 lebih komprehensif, tidak parsial. Dengan demikian, penyelesaian atas persoalan ini nampaknya tidak tepat kalau ditempuh dengan sekedar merubah UU tentang Susduk MPR, DPR, DPD dan DPRD.

Usulan yang sifatnya akademis tersebut memang masih memerlukan kajian yang lebih mendalam dan komprehensif. Tetapi penilaian bahwa hasil perubahan UUD 1945 masih memerlukan penyempurnaan nampaknya sebagian besar masyarakat sudah memahaminya. Untuk itu, sebelum melakukan perubahan (kelima) UUD 1945, sebaiknya disiapkan dahulu grand design agar nampak jelas sistem pemerintahan, sistem perwakilan dan sistem kekuasaan kehakiman (peradilan) yang dianut Indonesia. Pekerjaan besar ini sebaiknya dikerjakan oleh sebuah lembaga/ badan khusus semacam Komisi Konstitusi yang benar-benar independen, agar tidak terkontaminasi dengan kepentingan politik jangka pendek, apakah dibentuk atas dasar mandat dari MPR, dan hasilnya nanti disahkan oleh MPR, ataukah perlu diatur keberadaannya secara tegas di dalam UUD 1945.

\section{Usulan Amandemen Kekuasaan Kehakiman}

Kompleksitas persoalan kelembagaan pengemban kekuasaan kehakiman juga tidak kalah peliknya dan butuh penyelesaian segera. Beberapa persoalan yang berkaitan dengan Kekuasaan Kehakiman antara lain, pertama, putusan judicial review MK yang membatalkan kewenangan KY untuk mengawasi perilaku hakim, mengecualikan hakim konstitusi dari pengawasan KY, dan menyatakan KY bukan lembaga negara yang secara fungsional setingkat dengan MA dan MK (meskipun dimuat dalam satu Bab Kekuasaan Kehakiman), menarik untuk dikaji kembali secara mendalam tentang desain kekuasaan kehakiman dalam UUD 1945. Dampak dari pembatalan kewenangan pengawasan dalam UU KY tidak bisa direspon hanya dengan merubah UU KY, tetapi harus dibenahi dari desain konstitusionalnya dalam UUD 1945.

Kewenangan KY untuk mengawasi perilaku hakim ditentukan dalam Pasal 24B ayat (1) UUD 1945. Tepatkah putusan MK membatalkan kewenangan itu dan membuat tafsir sendiri bahwa kalau seluruh hakim sudah diseleksi oleh KY maka hakim-hakim inilah yang nantinya akan diawasi oleh KY. Sedangkan ketentuan didalam Pasal 24C ayat (3) UUD 1945 menegaskan, sembilan orang anggota hakim konstitusi yang 
ditetapkan oleh Presiden diajukan masing-masing tiga orang oleh MA, tiga orang oleh DPR, dan tiga orang oleh Presiden. Apakah dengan demikian hakim konstitusi terhindar dari pengawasan KY? Siapa yang mengawasi hakim konstitusi?

Ke depan, perlu diatur bahwa seluruh hakim baik hakim agung maupun hakim konstitusi pengusulannya harus dilakukan oleh KY. Sehingga seluruh hakim akan diawasi oleh pengawas ekternal yaitu KY. Baik MA maupun MK tidak perlu membentuk majelis kehormatan yang bertugas mengawasi perilaku hakim, yang anggotanya diambil dari lingkungan hakim itu sendiri. Hakim seharusnya bertugas menyelenggarakan proses peradilan, sedangkan urusan administratif misalnya pengawasan perilaku hakim, tidak perlu dikerjakan oleh sesama hakim. Dengan kata lain, tugas mengawasi hakim (hakim agung, hakim konstitusi dan hakim) cukup diserahkan kepada Komisi Yudisial. Hasil pengawasan Komisi Yudisial direkomendasikan kepada Ketua MA maupun Ketua MK untuk ditindaklanjuti. Dewan Kehormatan di MA maupun Majelis Kehormatan di MK bersifat ad hoc saja, dan mereka ada dan bertindak setelah adanya rekomendasi dari KY. Jadi tidak perlu permanen bentuknya.

Mengapa hakim konstitusi juga perlu diawasi oleh KY? Putusan MK yang menyatakan bahwa hakim MK tidak termasuk yang diawasi oleh KY, sesungguhnya tidak tepat karena hakim konstitusi juga hakim yang perlu diawasi perilakunya oleh lembaga pengawas eksternal supaya tidak terjadi disparitas pengawasan oleh KY terhadap pelaku kekuasaan kehakiman. Dengan putusan tersebut justru terjadi conflict of interest dalam diri MK. Apalagi putusan MK dalam uji materi UU KY tersebut bersifat ultra petita. Selain UU KY, putusan MK yang ultra petita misalnya UU KKR, UU KPK (kasus Pengadilan Tipikor) dll. Potensi menyimpang dari MK pun sesungguhnya perlu diawasi, supaya MK tidak tumbuh menjadi super body menggantikan MPR di masa lalu.Perlu dipikirkan kembali oleh lembaga legislatif berkenaan dengan kewenangan MK dalam pengujian undang-undang. Benarkah MK lembaga penafsir konstitusi? Sejauhmana kewenangan MK dalam menafsirkan konstitusi? Nampaknya juga perlu rambu-rambu yang jelas dan tegas. Pemberian kewenangan pengujian undang-undang kepada MK tanpa adanya pembatasan tertentu juga berpotensi terjadinya penyelewengan kekuasaan. Terbukti beberapa putusan MK yang ultra petita menimbulkan 'kekacauan baru' dalam perspektif yuridis maupun politis. 
Moh. Mahfud MD, ${ }^{22}$ mengusulkan untuk melakukan hak uji materiil kewenangan MK perlu dibatasi oleh minimal 3 hal sebagai berikut. Pertama, dalam membuat putusan, MK tidak boleh memuat isi yang bersifat mengatur. MK hanya boleh menyatakan sebuah UU atau sebagian isinya batal karena bertentangan dengan bagian tertentu di dalam UUD. Betapapun MK mempunyai pemikiran yang baik untuk mengatur sebagai alternatif atas UU atau sebagian isi UU yang dibatalkannya, sebab urusan mengatur itu adalah hak lembaga legislatif. Kedua, MK tidak boleh memutus batal atau tidak batal sebuah UU atau sebagian isi UU yang bersifat terbuka yakni yang oleh UUD diatribusikan (diserahkan pengaturannya) kepada UU. Kalau Mk melakukan itu, berarti ia sudah masuk ke ranah legislatif yang tidak boleh dilakukannya. Ketiga, MK tidak boleh memutus hal-hal yang tidak diminta (ultra petita). Betapa pun MK melihat ada sesuatu yang penting dalam sebuah permintaan dan dianggap penting untuk diminta, maka jika hal itu tidak diminta untuk diuji, MK tidak boleh melakukan itu. Kalau hal itu dilakukan, maka selain melanggar prinsip bahwa MK hanya boleh memutus hal yang secara jelas diminta, MK juga melanggar asas umum di dalam hkum bahwa setiap permintaan pemeriksaan harus diuraikan dalam 'posita' yang jelas yang juga dimuat dalam Peraturan MK sendiri.

Gagasan amandemen UUD 1945 yang meniadakan penjenjangan kelembagaan negara dan beralih kepada sistem pemisahan kekuasaan (horizontal) dimaksudkan supaya ada keseimbangan dan saling mengawasi diantara lembaga negara. Kalau prinsip checks and balances tidak lagi dihormati oleh masing-masing lembaga negara untuk apa kita memilih sistem itu ke dalam ketatanegaraan kita.

MPR perlu mengkaji ulang kewenangan pengujian UU oleh MK, apakah MK akan diberi kewenangan judicial review (JR), judicial preview $(J P)$, ataukah kedua-duanya. ${ }^{23}$ Kalau MK akan tetap diberi kewenangan judicial review, maka harus ditegaskan rambu-rambunya dalam konstitusi, apa yang boleh dan tidak boleh dilakukan oleh MK. Kalau MK diberi kewenangan judicial preview, maka pertama, kewenangan MK tersebut bersifat aktif ataukah pasif; kedua, apakah kewenangan tersebut berlaku untuk semua RUU ataukah RUU tertentu. Judicial preview MK tentu dapat dimanfaatkan ketika terjadi permasalahan sebagaimana yang diatur

${ }^{22}$ Lihat usulan Moh. Mahfud MD. dalam bukunya, Perdebatan Hukum Tata Negara, LP3ES, Jakarta, 2007, hlm. 98-99. 
dalam Pasal 20 ayat (5) UUD 1945. Jika presiden tidak mau mengesahkan RUU yang telah disetujui bersama, maka MK dapat diminta untuk melakukan judicial preview apakah sikap presiden yang tidak mau menandatangani RUU dapat dibenarkan ataukah sebaliknya tindakan presiden salah. Kalau kedua model ini (JR dan JP) diberikan kepada MK, maka perlu ada kajian mendalam apakah suatu RUU yang telah di judicial preview setelah disahkan menjadi UU juga dapat diajukan kembali melalui judicial review. Disamping itu, perlu diintegrasikan kewenangan pengujian perundang-undangan di MA dialihkan di bawah satu atap MK.

Ketiga, kemajemukan lembaga peradilan khusus harus jelas desainnya dalam bingkai kekuasaan kehakiman. Ketika UU No. 4 Tahun 2004 telah membuat kebijakan (politik) satu atap, ternyata beberapa peradilan khusus mulai dibentuk, seperti peradilan perikanan, peradilan agraria, peradilan pajak, peradilan perindustrian, dan peradilan profesi kedokteran, peradilan tipikor, peradilan HAM, dll. Anehnya, berkembang biaknya peradilan khusus tersebut sama sekali tidak melibatkan Mahkamah Agung. ${ }^{24}$ Kemana peradilan khusus itu akan bermuara atau akan ditangani sendiri oleh instansi yang bersangkutan, tidak ada kejelasan.

Keempat, nampaknya perlu dipikirkan pula dalam agenda perubahan (kelima) UUD 1945 mengenai pengaduan konstitusional (constitutional complaints) menjadi salah satu tambahan kewenangan Mahkamah Konstitusi. Karena UUD 1945 belum mengatur siapa yang berwenang menangani serta mengadili kasus pengaduan konstitusional oleh perorangan dengan alasan bahwa hak-hak asasinya selaku warga negara atau salah satu hak asasinya yang termaktub dalam konstitusi telah dilanggar oleh pejabat publik..$^{25}$

Dari beberapa persoalan kelembagaan di bidang kehakiman tersebut, revisi UU KY, UU MA maupun UU MK bukanlah jalan keluar yang tepat untuk mengatasi carut marutnya penegakan hukum di Indonesia. UUD 1945 harus memetakan secara tepat dan cermat desain kekuasaan kehakiman Indonesia.

${ }^{23}$ Lihat Jimly Asshiddiqie, Model-model Pengujian Konstitusional Di Beberapa Negara, Konstitusi Press, Jakarta, 2005.

${ }^{24}$ Kompas, 23 September 2004.

${ }^{25}$ Lihat juga M. Laica Marzuki, Berjalan-jalan Di Ranah Hukum, Buku Kesatu, Sekretariat Jenderal dan Kepaniteraan Mahkamah konstitusi RI, Jakarta, 2006, hlm. 91. 


\section{Penutup}

Tidak ada karya manusia yang sempurna, karena kesempurnaan itu hanya milik Allah swt. Untuk itu, munculnya gagasan amandemen 'ulang' UUD 1945 semata-mata untuk menyempurnakan kekurangan yang masih ada dari hasil amandemen sebelumnya, perlu mendapat respon positif dari MPR RI. Nampaknya, tahun 2008 waktu yang tepat untuk memulai mengkaji ulang secara komprehensif semua usulan amandemen ulang UUD 1945 yang diusulkan sejumlah kalangan maupun yang pernah diusulkan Komisi Konstitusi. Tidak perlu mensakralkan UUD 1945 seperti zaman Orde Baru, tetapi juga jangan terlalu mudah mengubah UUD.

\section{Daftar Pustaka}

A. Mukthie Fadjar, Reformasi Konstitusi Dalam Masa Transisi Paradigmatik, In-TRANS, Malang, 2003.

, Hukum Konstitusi dan Mahkamah Konstitusi, Konstitusi Press, Jakarta dan Citra Media, Yogyakarta, 2006.

Bagir Manan, Teori dan Politik Konstitusi, FH UII Press, Yogyakarta, 2003. Bambang Widjojanto dkk. (Editor), Konstitusi Baru Melalui Komisi Konstitusi Independen, Pustaka Sinar Harapan, 2002.

Guillermo O'Donnel, Philippe C. Schmitter dan Laurence Whitehead (Editor), Transition from Authoritarian Rule: Prospect for Democracy, 1986.

Jimly Asshiddiqie, Pergumulan Peran Pemerintah dan Parlemen Dalam Sejarah

Telaah Perbandingan Konstitusi Berbagai Negara, UI Press, Jakarta, 1996 - Model-model Pengujian Konstitusional Di Beberapa Negara, Konstitusi Press, Jakarta, 2005.

Komisi Konstitusi, Buku I Naskah Akademik Kajian Komprehensif Komisi Konstitusi tentang Perubahan UUD Negara Republik Indonesia Tahun 1945, MPR RI, Jakarta, 2004.

Krisna Harahap, Konstitusi Republik Indonesia Sejak Proklamasi Hingga Reformasi, PT Grafitri Budi Utami, Jakarta, 2004.

M. Laica Marzuki, Berjalan-jalan Di Ranah Hukum, Buku Kesatu, Sekretariat Jenderal dan Kepaniteraan Mahkamah konstitusi RI, Jakarta, 2006. Moh. Mahfud MD., Perdebatan Hukum Tata Negara, LP3ES, Jakarta, 2007. Mustofa Muchdhor (Penyunting), Bikameral Bukan Federal, Kelompok DPD di MPR RI, Jakarta, 2006.

Jurnal Demokrasi \& HAM, Vol.1, No. 4, September-November 2001. 
“Dekrit Bukan Solusi”, Kompas, 7 Juli 2006.

Adnan Buyung Nasution, "Kembali Ke UUD 45 Antidemokrasi", Kompas, 10 Juli 2006.

“Upaya Kembali ke Konstitusi Lama Harus “Dilawan”, Kompas, 6 Pebruari 2007.

Kompas, 6 Maret 2007.

Kompas, 7 Maret 2007.

Kompas, 31 Januari 2008.

Kompas, 1 Pebruari 2008. 